\title{
FIRST PRINCIPLES CALCULATION OF MANGANESE BASED HALF HEUSLER COMPOUNDS
}

\author{
(D) Lalit Mohana, (DSukhendera, (D)Sudesh Kumar'b (Deepak Sharma ${ }^{\mathrm{c}}$, \\ (iD)Ajay Singh Verma*,a \\ ${ }^{a}$ Department of Physics, Banasthali Vidyapith, Banasthali 304022, India \\ ${ }^{b}$ Department of Chemistry, Banasthali Vidyapith, Banasthali 304022, India \\ ${ }^{c}$ Department of Physics, IIMT College of Engineering, Greater Noida, 201306, India \\ *Corresponding Author: ajay_phy@rediffmail.com \\ Received March 30, 2020; accepted May 27, 2020
}

The Half-Heusler compounds exhibit a diverse range of tuneable properties including half-metallic ferromagnetism topological insulator, solar cells and thermoelectric converters. We have studied four half-Heusler compounds MnFeIn, MnFeGa, MnNiAs and $\mathrm{MnNiSb}$. The nature and properties of half-heusler compounds can be studied on the bases of their valance electron count. In this paper, Fe based compounds have 18 valence electrons; whereas 22 valence electrons in Ni based. The Density Functional Theory (DFT) has been performed with WIEN2k code. Ni based compounds with Mn located at octahedral sites are half-metals as revealed from the Density of States (DoS) and band structure calculations. In all of them, spin-up channels are conducting; whereas in MnNiAs and MnNiSb spin-down channels have the small band gaps. MnNiAs and MnNiSb exhibit half-metallic property with integer magnetic moments of $4 \mu_{\mathrm{B}}$ per formula unit and half-metallic gaps of 0.15 and $0.17 \mathrm{eV}$ at their equilibrium volume respectively.

KEYWORDS: Half-heusler, Spin polarisation, Optimization, Half- metallic

\section{INTRODUCTION}

The Heusler compounds were named after its discoverer Fritz Heusler. Surprisingly, the compound is ferromagnetic although none of its constituent elements is magnetic by itself. Half-Heusler compound is an impressive group of unconventional semiconductors being comprised of metal and containing at least one transition metal. Based on their properties they can be used in many applications [1-5]. The structure of Manganese based HalfHeusler compounds is a combination of rock salt and Zinc blend type lattices. This class of compounds with a 1:1:1 stoichiometric composition and can be represented as XYZ type structure with space group F-43 m [6, 7]. The main group elements such as $\mathrm{As}, \mathrm{Ga}$, In and $\mathrm{Sb}$ represents $\mathrm{Z}$ in our study. These compounds can be viewed as $\mathrm{Mn}$ and $\mathrm{Z}$ form zinc blend sub lattice arranged in a primitive cell at Wyckoff positions $(0,0,0)$ and $\left(\frac{1}{2}, \frac{1}{2}, \frac{1}{2}\right)$ whereas $[8,9]$. We can also mention the ordering by interchanging above said Wyckoff positions, but the preferred atomic arrangements have dependency on size of involved atoms and the inter-atomic interaction between them. But in our case the size dependency on arrangement of transition metal is dominating factor over inter-atomic interaction configured by electro negativity of atoms. So, Manganese is most electropositive atom in our series of interest occupies position $(0,0,0)$ whereas p-block elements are most electronegative element arranged at $(0.5,0.5,0.5)$ for such set of configuration the transition elements having intermediate electronegativity acts like a bridge to pass on valence electrons from electropositive to most electronegative atom. This bridge type consideration forwarded by electronegativity difference plays important role for determination of bonding nature of materials. Also, half Heusler compounds considered as ternary relatives of binary semiconductors with vacant tetrahedral structures [10, 11]. The properties of these compounds depend strongly on number of valance electron in the primitive cell which determine the band structure \& physical properties of the compound. Generally, it has been observed that half Heusler compounds with 18 valence electron having closed shell configuration shows tuneable band gap apart from this phase compounds will show magnetic behaviour but manganese-based compounds show tuneable band gap with 22 valence electrons instead of $18[12,13]$. Such behaviour can also be seen in rare earth metal based half Heusler compounds $[14,15]$.

\section{COMPUTATIONAL DETAILS}

The first principles calculations are done by using full potential Linearized Aungumated Plane Wave method (FP-LAPW) implemented in WIEN2k simulation package to describe the interaction between atomic core and valence electrons [16]. Considering the valance electrons, the electronic wave function is expanded. Generalized gradient approximation (GGA) in Perdew-Burke-Ernzerhof (PBE) is used to describe the exchange correlation energy [17]. For the geometry optimization of electronic structure; we have used the FP-LAPW method which lies within the framework of spin-polarized Density Functional Theory (SDFT). The cut-off energy separation between core and band states is kept -0.6 Ry for plane wave basis set in all studied materials. The energy convergence criterion was set to $0.00001 \mathrm{Ry}$ and for charge to $0.001 \mathrm{e}$. Total numbers of K - point are kept 1000 for irreducible Brillouin zones in Wien $2 \mathrm{k}$. 


\section{RESULT AND DISCUSSION}

In the first step, the lattice constants were determined. The total energies for mentioned compounds with halfHeusler structure as a function of the lattice constant are calculated. The equilibrium lattice constants were derived by minimizing the total energy.

\section{Structural properties}

For all compounds volume optimization was done based on the Murnaghan equation of state [18]. The volume vs. energy curves are shown in Fig. 1. The optimized volume, pressure, pressure derivative and the minimum ground state energy is calculated and tabulated in Table 1. The optimized value of the lattice constant was used for the DOS, band structures and magnetic moment calculations to predict the electronic and magnetic properties of compounds.

Table 1.

The calculated values of the equilibrium lattice constant $\mathrm{a}_{0}$, equilibrium volume, the bulk modulus B (GPa), the pressure derivative of bulk modulus $\mathrm{B}_{\mathrm{P}}$ and minimum energy during optimization.

\begin{tabular}{|c|c|c|c|c|c|}
\hline Compound & $\begin{array}{c}\text { Optimized Lattice } \\
\text { Parameter }\left(\mathbf{A}^{0}\right)\end{array}$ & $\begin{array}{l}\text { Equilibrium } \\
\text { Volume }\left(V_{0}\right)\end{array}$ & $\begin{array}{l}\text { Bulk Modulus } \\
\text { (GPa) }\end{array}$ & $\mathbf{B}_{\mathbf{P}}$ & Energy \\
\hline MnFeIn & 5.7057 & 341.56 & 140.90 & 3.34 & -16629.13 \\
\hline MnFeGa & 5.7048 & 313.22 & 101.56 & 4.58 & -5348.47 \\
\hline MnNiAs & 5.7048 & 305.23 & 141.97 & 7.40 & -9881.19 \\
\hline MnNiSb & 5.9128 & 348.81 & 102.37 & 6.02 & -18326.23 \\
\hline
\end{tabular}
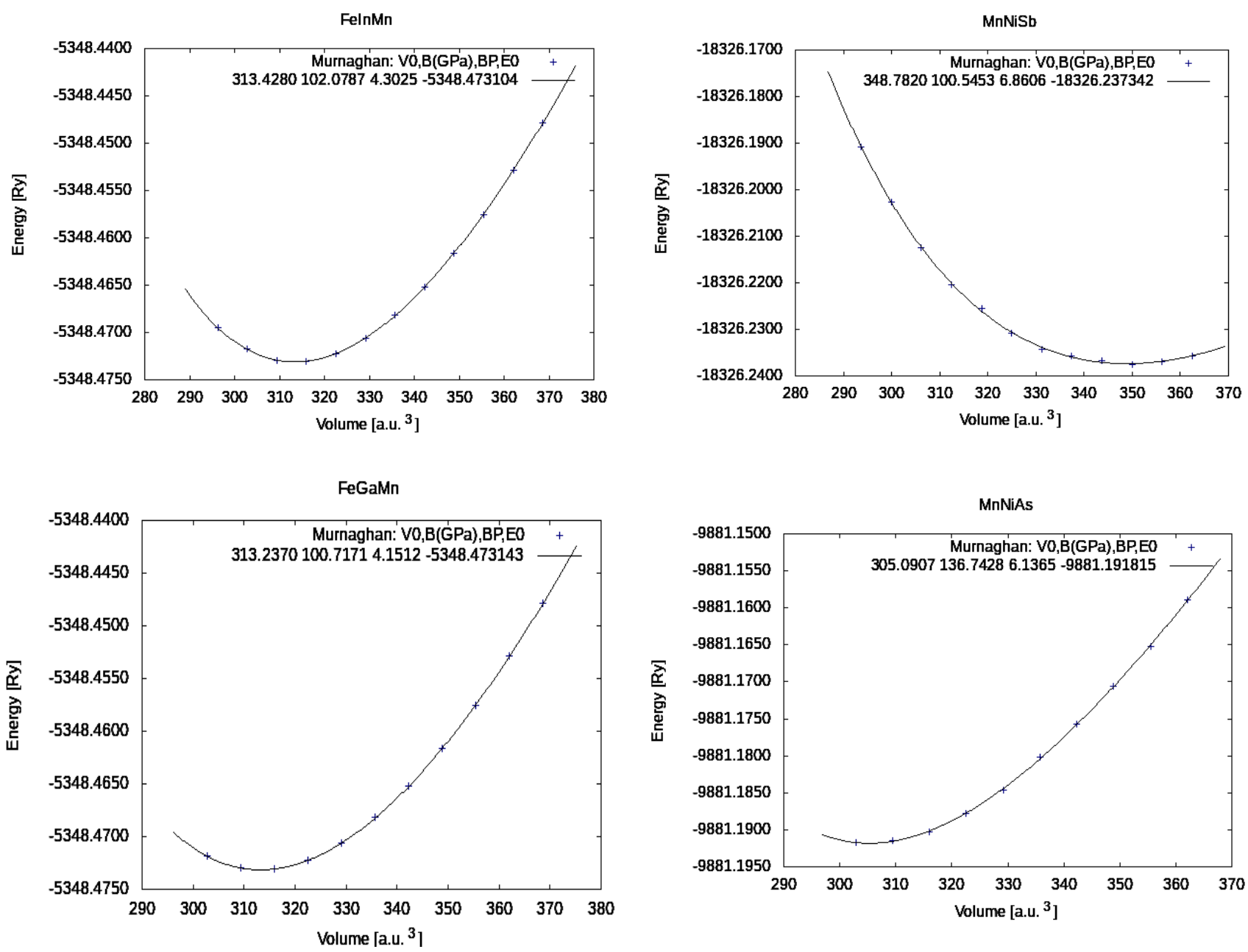

Figure 1. Total energy as a function of volume per formula unit corresponding to MnFeIn, MnFeGa, MnNiSb \& MnNiAs alloys 


\section{Electronic and Magnetic Properties}

The electronic structure plays an important role in determining the half-metallic properties of half-Heusler compounds, so in order to understand the electronic structure of compounds; we have calculated the total density of states (DOS) and shown in Fig. 2.
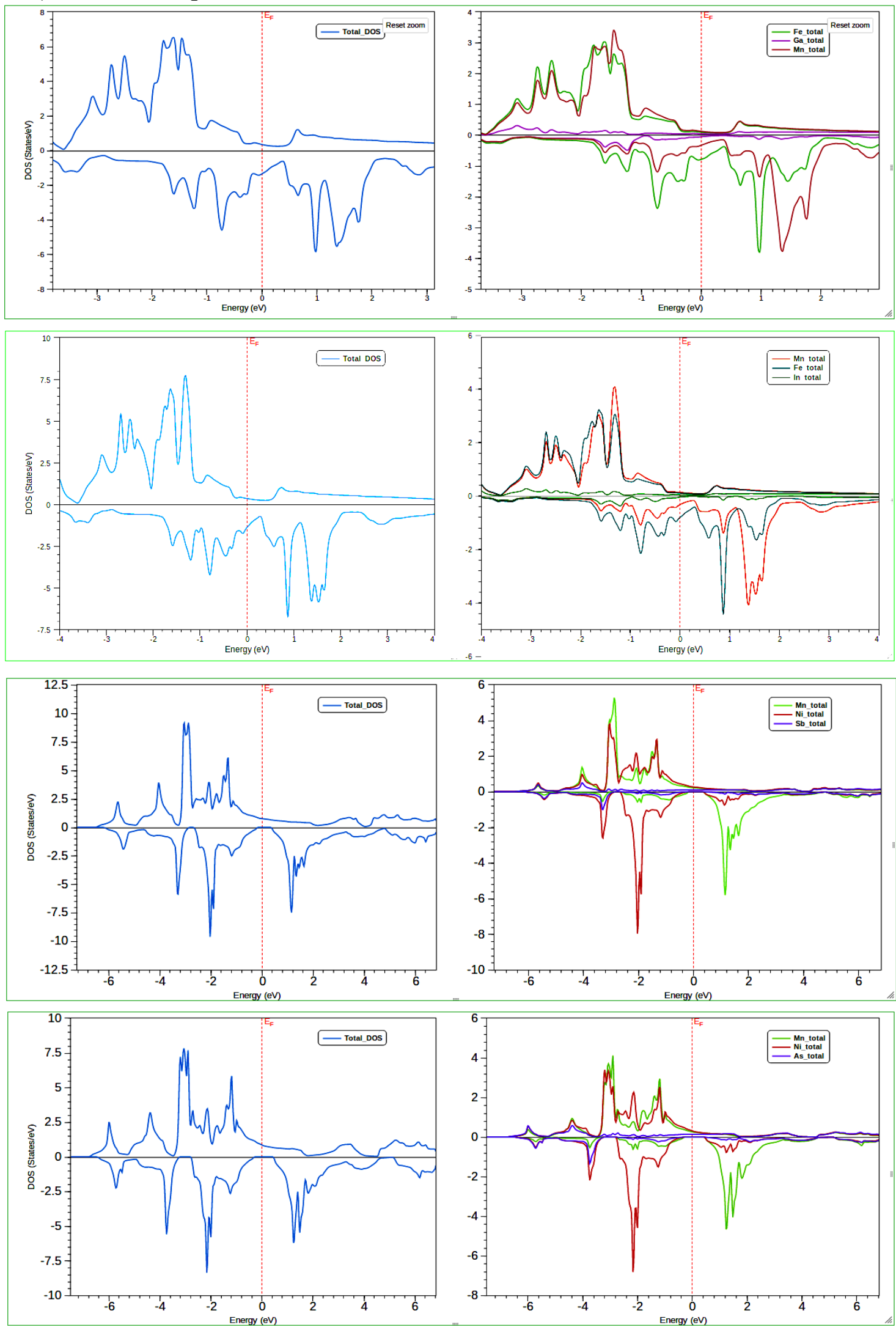

Figure 2. Total and atomic spin- density of states of all studied metallic (MnFeIn, MnFeGa) and half metallic ferromagnetic (MnNiSb, MnNiAs) compounds at their equilibrium lattice constant. Negative of DOS axis represents the minority spin 
It is clear from the figure for both $\mathrm{MnFeGa}$ and MnFeIn both the majority and minority spin electrons exhibits metallic character. For MnNiAs and MnNiSb compounds, the electronic states in the majority-spin band are metallic and there is an energy gap at the Fermi level in minority-spin state confirms the half-metallic characteristics at their equilibrium lattice constants. We have focused on the calculations of MnNiAs and $\mathrm{MnNiSb}$ compounds, and the origin of half-metallic band gaps for these compounds has investigated. The partial DOS are also shown in the Fig. 2 for all the four compounds. Because the half-metallic band gap is an important factor in these materials, the atomic-projected DOSs of MnNiAs and $\mathrm{MnNiSb}$ compound. The states around $-4.4 \mathrm{eV}$ to $-0.8 \mathrm{eV}$ are essentially composed of Ni-d states with some admixture of $\mathrm{As} / \mathrm{Sb}-\mathrm{p}$ and $\mathrm{Mn}-\mathrm{d}$ states. The states above $0.2 \mathrm{eV}$ are mainly composed of $\mathrm{Ni}$ and $\mathrm{Mn}-\mathrm{d}$ states. The Ni-d states are mainly located below the Fermi level, while the majority Mn-d states are mainly found around Fermi level. The ferromagnetism in MnNiAs and MnNiSb is attributed to the strong tendency of the delectrons of $\mathrm{Mn}^{3+}\left(\mathrm{d}^{4}\right)$ to localize. The $\mathrm{s}$ and $\mathrm{p}$ states of Arsenic and Antimony are fully occupied and hybridize with unoccupied $\mathrm{p}$ and $\mathrm{s}$ state of Nickel, forming a set of low energy bonding $a_{1}$ and triple degenerated $t_{2}$ orbital, as well as a set of high energy anti-bonding and unoccupied orbital forming. The coupling of sublattices $[\mathrm{NiAs}]^{3-}$ and $[\mathrm{NiSb}]^{3-}$ with $\mathrm{Mn}^{3+}$ atom leads to the formation of bonding orbital doubly occupied and filled with 18 valance electrons. The anti-bonding hybrid orbital occupies four valance electrons. $\mathrm{Mn}^{3+}$ with $\mathrm{d}^{4}$ configuration giving rise to a magnetic moment of approximately $4 \mu_{\mathrm{B}}$.

To determine the band gap, we have also calculated the band structures of Half-Heusler compounds as shown in the Fig. 3. Both the panels for spin-up (black) channels and for the spin-down (blue) are given. Spin-down states have the band gaps and are, therefore, semiconducting. In the minority-spin band structure of MnNiSb and MnNiAs, the valence band maximum (VBM) is at the $\Gamma$-point and the conduction band minimum (CBM) at the X-point. Thus, the minority-spin band structure shows half-metallic behaviour with an indirect energy gap. The origin of the gap is mainly attributed to the covalent hybridization between the d-states of the $\mathrm{Mn}$ and $\mathrm{Ni}$ atoms, leading to the formation of bonding and anti-bonding bands with a gap in between [19]. The bonding hybrids are localized mainly at the Ni atoms whereas the anti-bonding states are mainly at the Mn sites.

MnFeIn_OO atom 0 size 0.20

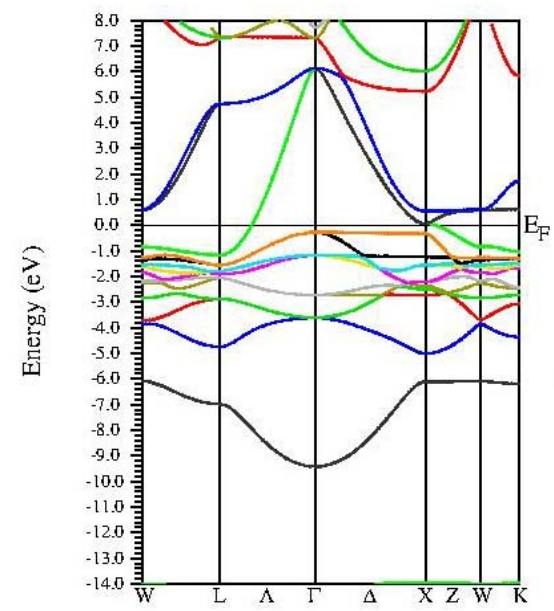

MnFeGa_Oatom 0 size 0.20

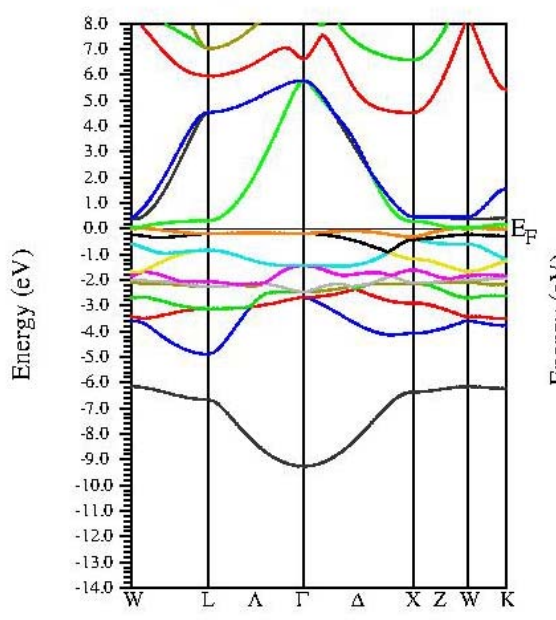

MnFeIn_OO atom 0 size 0.20

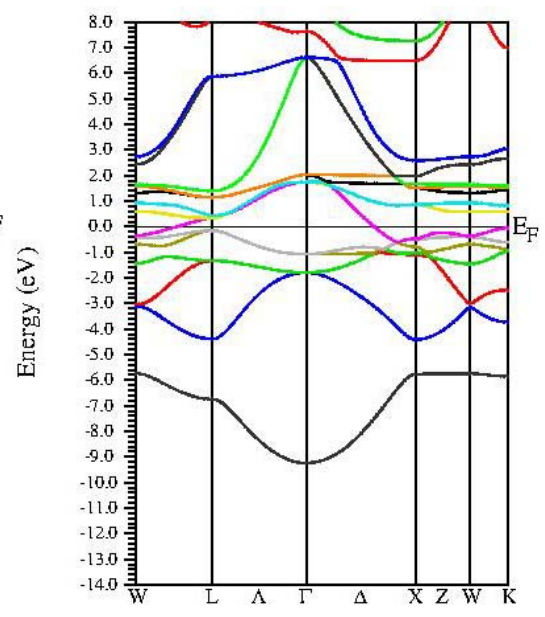

MnFeGa_O atom 0 size 0.20

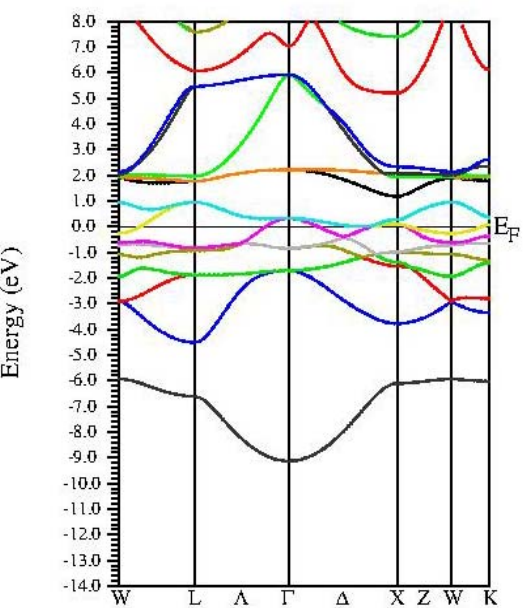

Figure 3. Spin resolved structure of compounds in majority spin channel (left) and minority spin channel (right), at the equilibrium lattice constant

(Continued on next page) 

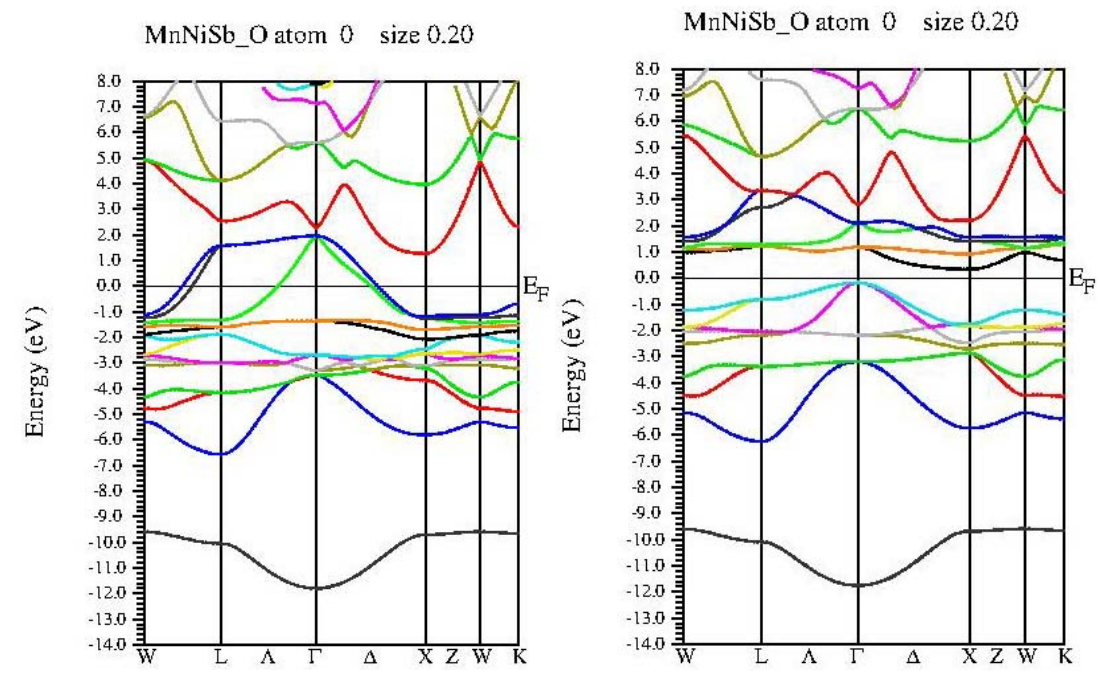

MnNiAs_Oatom 0 size 0.20
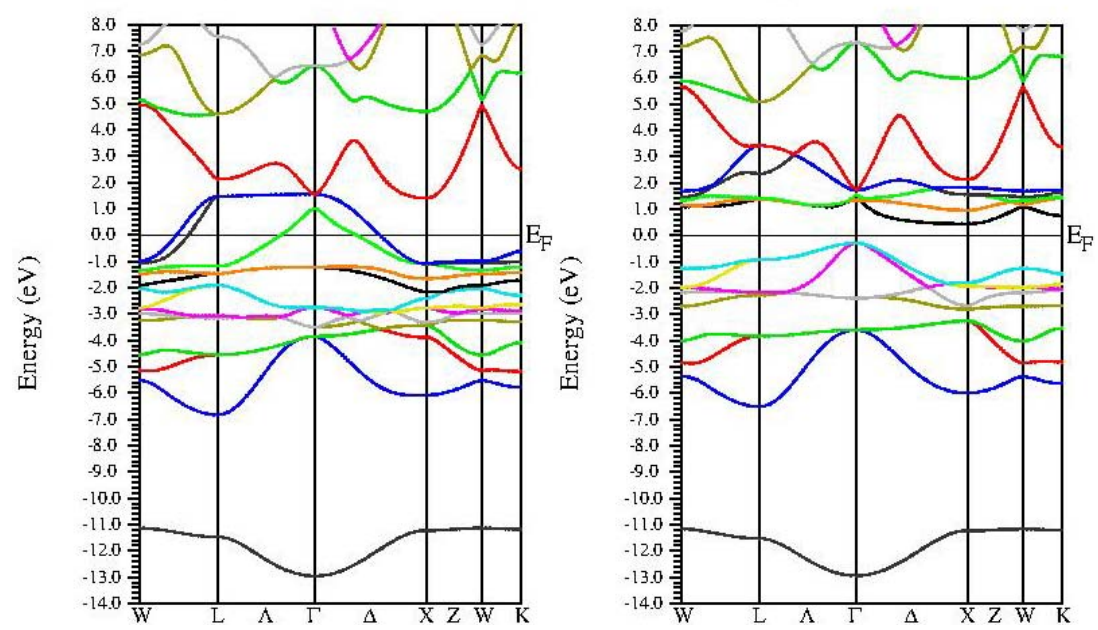

Figure 3. Spin resolved structure of compounds in majority spin channel (left) and minority spin channel (right), at the equilibrium lattice constant

(Continuation)

Here, we come to the magnetic properties of these Half-Heusler compounds. The Galanakis model describes the spin magnetic moment of half-Heusler compounds using the difference between spin-up and spin-down states [20,21]. The integral total magnetic moment, which is a typical characteristic of half metallic ferromagnetism, obeys the SlaterPauling rule for the half-Heusler alloys $\mathrm{M}_{t}=\mathrm{Z}_{\mathrm{t}}-18$; where $\mathrm{M}_{\mathrm{t}}$ is the total magnetic moment per formula unit and $\mathrm{Z}_{\mathrm{t}}$ is the total number of valence electrons [22,23]. For example, $\mathrm{Mn}, \mathrm{Fe}, \mathrm{Ni}, \mathrm{In}, \mathrm{Ga}, \mathrm{Sb}$ and $\mathrm{As}$ atoms have 7,8,10,3,3,5 and 5 valence electrons, respectively. The total magnetic moments per formula unit for these four compounds are integral and shown in table 2 .

Table 2.

Calculated values of total magnetic moments of the compounds

\begin{tabular}{|c|c|c|c|c|}
\hline $\boldsymbol{\mu}_{\mathbf{B}}$ & $\mathrm{Mn}$ & $\mathrm{Fe} / \mathrm{Ni}$ & $\mathrm{X}(\mathrm{In}, \mathrm{Ga}, \mathrm{Sb}, \mathrm{As})$ & Total \\
\hline $\mathrm{MnFeIn}$ & 3.291 & 2.367 & -0.338 & 5.32 \\
\hline $\mathrm{MnFeGa}$ & 3.21 & 2.342 & -0.42 & 5.132 \\
\hline $\mathrm{MnNiSb}$ & 3.883 & 0.298 & -0.181 & 4 \\
\hline $\mathrm{MnNiAs}$ & 3.812 & 0.332 & -0.145 & 3.999 \\
\hline
\end{tabular}

For example, $\mathrm{Mn}, \mathrm{Fe}, \mathrm{Ni}, \mathrm{In}, \mathrm{Ga}, \mathrm{Sb}$ and As atoms have 7,8,10,3,3,5 and 5 valence electrons, respectively. Also, the spin polarization $\mathrm{P}$ is defined by the total number of valence electrons and total magnetic moment per formula unit is shown in Table 3. It is clear that the compounds with 22 valance electrons are $100 \%$ spin polarized. The calculated result has good agreement with theoretical value of magnetic moment. 
Compound parameters

\begin{tabular}{|c|c|c|c|}
\hline Compound & $\mathbf{Z}_{\mathbf{t}}$ & $\mathbf{M}_{\mathbf{t}}\left(\boldsymbol{\mu}_{\mathbf{B}}\right)$ & Spin Polarization \\
\hline MnFeIn & 18 & Zero & Unpolarized \\
\hline MnFeGa & 18 & Zero & Unpolarized \\
\hline MnNiAs & 22 & 4 & $100 \%$ \\
\hline MnNiSb & 22 & 4 & $100 \%$ \\
\hline
\end{tabular}

\section{SUMMARY AND CONCLUSIONS}

Half-metallic behaviour of materials has been found and the applications in different aspects of the emerging field of spintronics, e.g. half-metallicity produces $100 \%$ spin polarization at the Fermi level; which generates a fully spinpolarized current. Furthermore, due to conduction of only one type of electrons, i.e. spin-up or down, they can be used as electrical switches. These properties make half-metals suitable for applications in Spintronics. We have been observed from theoretical calculations that Fe based half-Heusler compounds containing Mn at octahedral lattice have metallic behaviour inspite of they having 18 valance electron, whereas $\mathrm{Ni}$ based 22 valance electron alloys have band gap in their minority spin state.

\section{ORCID IDs}

(DLalit Mohan, https://orcid.org/0000-0003-3323-8296; - OSukhender, https://orcid.org/0000-0002-2149-5669

Dudesh Kumar, https://orcid.org/0000-0002-7507-4712; DDeepak Sharma, https://orcid.org/0000-0001-9163-9050

(D)Ajay Singh Verma, https://orcid.org/0000-0001-8223-7658

[1] K. Yang, W. Setyawan, S. Wang, M.B. Nardelli and S. Curtarolo, Nature Mater. 11, 614-619 (2012), https://doi.org/10.1038/nmat3332.

[2] S. Wang, Z. Wang, W. Setyawan, N. Mingo and S. Curtarolo, Phys. Rev. X, 1, 021012 (2011), https://doi.org/10.1103/PhysRevX.1.021012.

[3] T. Gruhn, Phys. Rev. B, 82, 125210 (2010), https://doi.org/10.1103/PhysRevB.82.125210.

[4] A. Roy, J.M. Bennett, K.M. Rabe, and D. Vanderbilt, Phys. Rev. Lett. $109 \quad 037602$ (2012), https://doi.org/10.1103/PhysRevLett.109.037602.

[5] Jiong Yang, Huanming Li, Ting Wu, Wenqing Zhang, Lidong Chen, and Jihui Yang, Adv. Funct. Mater. 18, 2880-2888 (2008), https://doi.org/10.1002/adfm.200701369.

[6] B.R.K. Nanda, and I. Dasgupta, J. Physics: Condensed Matter, 15, 7307 (2003), https://doi.org/10.1088/0953-8984/15/43/014.

[7] H.C. Kandpal, C. Felser, and R. Seshadri, J. Phys. D: Appl. Phys. 39(5), 776 (2006), https://doi.org/10.1088/0022-3727/39/5/S02.

[8] R. Allmann, and R. Hinek, Acta Cryst. A, 63, 412-417 (2007), https://doi.org/10.1107/S0108767307038081.

[9] P. Villars, and L.D. Calvert. Pearson's handbook of crystallographic data for intermetallic phases. (American Society for Metals, 1986).

[10] Zhang Xiuwen, Chinese Physics B, 27(12), 127101 (2018), https://doi.org/10.1088/1674-1056/27/12/127101.

[11] Feng Yan, Xiuwen Zhang, Yonggang G. Yu, Liping Yu, Arpun Nagaraja, Thomas O. Mason, and Alex Zunger, Nat. Commun. 6, 7308 (2015), https://doi.org/10.1038/ncomms8308.

[12] J. Tobola, and J. Pierre, J. All. Comp. 296, 243-252 (2000), https://doi.org/10.1016/S0925-8388(99)00549-6.

[13] T. Graf, C. Felser, and S.S.P. Parkin, Progress in Solid State Chemistry. 39(1), 1-50 (2011), https://doi.org/10.1016/j.progsolidstchem.2011.02.001.

[14] L. Zhang, X. Wang, and Z. Cheng, J. Alloys and Compounds, 7, 16183 (2017), https://doi.org/10.1016/j.jallcom.2017.05.116.

[15] K. Gofryk, D. Kaczorowski, T. Plackowski, A. Leithe-Jasper, and Yu. Grin, Phys. Rev. B, 84, 035208 (2011), https://doi.org/10.1103/PhysRevB.84.035208.

[16] P. Blaha, K. Schwarz, G.K.H. Madsen, D. Kvasnicka, J. Luitz, R. Laskowski, F. Tran, and L.D. Marks, WIEN2k, An Augmented Plane Wave + Local Orbitals Program for Calculating Crystal Properties, edited by K. Schwarz (Technical Universitatwien, Austria, 2001), http://susi.theochem.tuwien.ac.at/reg_user/textbooks/usersguide.pdf.

[17] J.P. Perdew, K. Burke, and M. Ernzerhof, Phys. Rev. Lett. 77, 3865 (1996), https://doi.org/10.1103/PhysRevLett.77.3865.

[18] S. Ouardi, G.H. Fecher, B. Balke, X. Kozina, G. Stryganyuk, C. Felser, S. Lowitzer, D. Ködderitzsch, H. Ebert, and E. Ikenaga, Phys. Rev. B, 82, 085108 (2010), https://doi.org/10.1103/PhysRevB.82.085108.

[19] I. Galanakis, P.H. Dederichs, and N. Papanikolaou, Phys. Rev. B, 66, 134428 (2002), https://doi.org/10.1103/PhysRevB.66.134428.

[20] I. Galankis, and P.H. Dederiches, Half-metallic Alloys: Fundamentals and Applications, (Springer, Berlin, 2005), ISBN 103540277196.

[21] I. Galanakis, P.H. Dederichs, and N. Papanikolaou, Phys. Rev. B, 66, 174429 (2002), https://doi.org/10.1103/PhysRevB.66.174429.

[22] I. Galanakis, P. Mavropoulos, and P.H. Dederichs, J. Physics D: Applied Physics, 39, 765 (2006), https://doi.org/10.1088/00223727/39/5/S01.

[23] C. Felser, G.H. Fecher, and B. Balke, Angewandte Chemie International Edition, 46, 668 (2007), https://doi.org/10.1002/anie.200601815. 


\section{ПЕРШООСНОВИ РОЗРАХУНКІВ НАПІВХЕЙСЛЕРОВИХ СПОЛУК НА ОСНОВІ МАРГАНЦЮ \\ Лаліт Мохан ${ }^{a}$, Сухендер $^{a}$, Судеш Кумар ${ }^{b}$, Діпак Шарма ${ }^{c}$, Аджай Сінгх Верма ${ }^{a}$ \\ ${ }^{a}$ Фізичний факультет, Банастхалі Від'япіт, Банастхалі, 304022, Індія

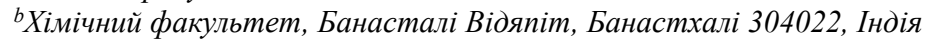 \\ 'Фізичний факультет, інженерний коледж IIMT, Велика Нойда, 201306, Індія}

Напівхейслерові сполуки мають різноманітні властивості застосування включаючи напівферомагнітні топологічні ізолятори, сонячні елементи і термоелектричні перетворювачі. Ми досліджували чотири напівхейслерові сполуки: $\mathrm{MnFeIn,} \mathrm{MnFeGa,}$ MnNiAs i MnNiSb. Природа і властивості напівхейслерових сполук може бути вивчена на основі розрахунку їх валентних електронів. У цій статті сполуки на основі Fе містять 18 валентних електронів; тоді як сполуки на основі Ni містять 22 валентних електрона. Функціональна теорія щільності (DFT) була розроблена з використанням коду WIEN2k. Сполуки на основі $\mathrm{Ni}$ з Mn, що розташовані в октаедричних зонах, $\epsilon$ напівметалами, як це випливає з розрахунків густини станів і зонної структури. У всіх них канали з орієнтацією спіну вгору є такими, що проводять, тоді як в MnNiAs i MnNiSb канали 3 орієнтацією спіну вниз мають малу енергетичну щілину. MnNiAs i MnNiSb проявляють напівметалеві властивості 3 цілочисельними магнітними моментами в $4 \mu$ в на формульну одиницю і відповідно мають напівметалеві проміжки 0,15 i 0,17 еВ, при їх рівноважному об'ємі.

КЛЮЧОВІ СЛОВА: напівхейслерові сполуки, спінова поляризація, оптимізація, напівметалевий

\section{ПЕРВООСНОВЫ РАСЧЕТА ПОЛУХЕЙСЛЕРОВЫХ СОЕДИНЕНИЙ НА ОСНОВЕ МАРГАНЦА} Лалит Мохан ${ }^{a}$, Сухендер $^{a}$, Судеш Кумар ${ }^{b}$, Дипак Шарма ${ }^{c}$, Аджай Сингх Верма ${ }^{a}$

${ }^{a}$ Физический факультет, Банастхали Видьяпит, Банастхали, 304022, Индия

${ }^{b}$ Химический факультет, Банастали Видяпит, Банастхали 304022, Индия

сФизический факультет, инженерный колледж ИИМТ, Большая Нойда, 201306, Индия

Полухейслеровы соединения имеют различные свойства применения включая полуферомагнитные топологические изоляторы, солнечные элементы и термоэлектрические преобразователи. Мы исследовали четыре полухейслеровы соединения: MnFeIn, MnFeGa, MnNiAs и MnNiSb. Природа и свойства полухейслеровых соединений может быть изучена на основе расчета их валентных электронов. В этой статье соединения на основе Fе содержат 18 валентных электронов; тогда как соединения на основе Ni содержат 22 валентных электрона. Функциональная теория плотности (DFT) была разработана с использованием кода WIEN2k. Соединения на основе Ni c Mn, расположенных в октаэдрических зонах, являются полуметаллами, как это следует из расчетов плотности состояний и зонной структуры. Во всех них каналы с ориентацией спина вверх являются проводящими, тогда как в MnNiAs и MnNiSb каналы с ориентацией спина вниз имеют малую энергетическую щель. MnNiAs и MnNiSb проявляют полуметаллические свойства с целочисленными магнитными моментами в $4 \mu \mathrm{B}$ на формульную единицу и соответственно имеют полуметаллические промежутки 0,15 и 0,17 эВ, при их равновесном объеме.

КЛЮЧЕВЫЕ СЛОВА: полухейслеровые соединения, спиновая поляризация, оптимизация, полуметаллический 